\title{
Acidity Control Utilizing Different Soil Management Methods in Italian Ryegrass and Silage Maize Production Systems
}

Jéssica Alves Nogaroli ${ }^{*}$

https://orcid.org/0000-0002-3184-6661

\author{
Adriel Ferreira da Fonseca ${ }^{2}$ \\ https://orcid.org/0000-0002-2773-3250
}

\section{Gabriel Barth ${ }^{3}$}

https://orcid.org/0000-0002-8669-0588

\begin{abstract}
${ }^{1}$ Tuiuti of Paraná University, Faculty of Exact Sciences and Technology, Barigui Campus, Curitiba, Paraná, Brazil; 2State University of Ponta Grossa (UEPG), Department of Soil Science and Agricultural Engineering - Uvaranas Campus, Ponta Grossa, Paraná, Brazil; ${ }^{3}$ ABC Foundation, Castro, Paraná, Brazil.
\end{abstract}

Received: 2019.08.22; Accepted: 2020.01.27.

*Correspondence: jessica.nogaroli@utp.br; Tel.: +55-42-999652859 (F.L.)

\section{HIGHLIGHTS}

- Use of Italian ryegrass as cover crop decreases soil acidity in the $0-5 \mathrm{~cm}$ soil layer.

- The Italian ryegrass as silage reduces soil acidity down to the 30-cm soil layer.

- Integrated crop-livestock reduces soil acidity variability in the medium-term.

- In the medium-term, Italian ryegrass and silage maize favor a residual liming effect.

\begin{abstract}
This study examined the effects of liming on soil acidity and base saturation (V) in Italian ryegrass (ryegrass) and silage maize production systems over the medium-term. A split-plot design with four replications was employed on Humic Hapludox. The plots consisted of four soil management methods: conventional tillage (CT), minimum tillage (MT), no-tillage (NT) and chiselled NT (CNT). Within the split plots, ryegrass was used as cover crop (CC), silage (S), and integrated crop-livestock (ICL) system. Following ryegrass phytomass the maize was sowed. Once the maize had been cut with a silage machine, soil samples were collected from the layers $0-5,5-10,10-15,15-20$ and $20-30 \mathrm{~cm}$ at 24 and 60 months after liming. The attributes $\mathrm{pH}, \mathrm{H}+\mathrm{Al}$, exchangeable aluminium $\left(\mathrm{Al}^{3+}\right)$, and $\mathrm{V}$ were evaluated. The highest $\mathrm{pH}$ and $\mathrm{V}$ values were observed in the $0-5 \mathrm{~cm}$ layer in NT. The CNT did not result in improvement of acidity conditions or V. The ryegrass as $S$ and ICL decreased soil acidity from $10 \mathrm{~cm}$ layer. NT combined with ICL provided soil acidity improvements 60 months after liming. Therefore, the exploration of winter with Italian ryegrass may elicit greater benefits in deep soil layers than cover crops.
\end{abstract}

Keywords: soil reaction; integrated crop-livestock; variable charge soil. 


\section{INTRODUCTION}

In the region of Campos Gerais (Paraná -Brazil), most rural properties conduct agricultural and animal science activities, usually planting silage maize during spring and summer, and Italian ryegrass (ryegrass) during fall and winter. Maize which serves as a major source of farm livestock silage feed, and ryegrass which provides sufficient biomass via grazing, both perform favorably in NT systems [7]. However, few silage maize and ryegrass production system studies have considered the effects on soil acidity variation and soil base saturation (V) in the medium-term up to $30 \mathrm{~cm}$ of depth.

Modern systems include integrated sustainable agricultural and animal science practices. In such a context integrated crop-livestock (ICL) when combined with NT, provides intense food production in a sustainable manner [25], favors nutrient cycling and soil improvement [29], and maintains a high crop yield [3] depending on a variety of factors related to the type of soil, plant, and animal, as well as atmospheric conditions [10]. However, in ICL, the soil acidification process may occur due to intense land exploitation [5] over the long term. Therefore, appropriate management techniques, including soil acidity control, are fundamental to achieving a sustainable level of agricultural production.

The soil acidification process might occur due to the following factors: (i) rainfall where there is deposition of sulphuric and nitric acids, sulphur dioxide, and ammonium ions [5], besides protons $\left(\mathrm{H}^{+}\right)$and bicarbonate $\left(\mathrm{HCO}^{3-}\right.$ ) releases; (ii) leaching of basic cations (Calcium $-\mathrm{Ca}^{2+}$, Magnesium $-\mathrm{Mg}^{2+}$ and Potassium $-\mathrm{K}^{+}$); (iii) cation uptake and exportation by the crop; (iv) hydrolysis reactions in the humic-clay plasma; and (v) the addition of soluble salts and fertilizers (mineral and organic) in the soil-plant system [19]. Furthermore, in ICL other factors should be considered such as the presence of animals [22] where there is grazing with increased proton release $\left(\mathrm{H}^{+}\right)$in the system [4,26]; increased biopores associated with controlled grazing [2] that results from intense renovation (re-sprouting) of the forage (aerial and root portion) [4]; and urine flux up until soil deep layers [23]. Thus, factors that might accelerate soil acidification are the same as those that favor the dissolution of limestone in the soil. The best strategy to correct the soil is to apply limestone which reduces the acidification effects, creating favorable conditions for economically viable grain and animal production [5]. Therefore, in ICL is expected that vegetal and animal residues along with the soil management methods will act as catalyst agents on limestone dissolution and on effect residual of limestone in soil up to the $30-\mathrm{cm}$ layer.

Considering the above-mentioned points, the objective of this study was to verify in the medium term the effects of liming on ryegrass and silage maize production systems regarding changes in the $\mathrm{pH}, \mathrm{H}+\mathrm{Al}$, exchangeable $\mathrm{Al}^{3+}$ and $\mathrm{V}$ up to $30 \mathrm{~cm}$ of depth.

\section{MATERIAL AND METHODS}

\section{Site and Experimental Design}

The experiment (lat:2447; long:4950; alt:997 m) was carried out in Castro (PR - BR), in Humic Hapludox soil. This area was growthed for over 10 years under no-tillage (NT) with soybean, maize, wheat and black oat. During this study, the temperature average and air relative humidity were of $17.4^{\circ} \mathrm{C}$ and $87.8 \%$, respectively. Already, the accumulation rainfall was of $639 \mathrm{~mm}$ during 2009 to 2014. Between these years, soil management methods were employed and Italian ryegrass (Fall-Winter) and silage maize (SpringSummer) were growthed in succession. The liming occurred in March/2009. Data from the study was considered from 2009. The experimental design was completely randomized blocks in split-plot with four replications. In the plots $\left(300 \mathrm{~m}^{2}\right)$ were studied four soil management methods: (i) conventional tillage (CT), (ii) minimum tillage (MT), (iii) NT and (iv) chiselled NT (CNT). In CT and MT, the soil was prepared annually before sowing the ryegrass crop using a plow and levelling harrow at 0.20 and $0.10 \mathrm{~m}$ average depths, respectively. In NT, the soil was only upturn in the sowing/fertilizing furrow. In CNT, the soil was chiselled at $0.30 \mathrm{~m}$ depth in 2009, 2011 and 2013 and before sowing of ryegrass. In the subplots $\left(100 \mathrm{~m}^{2}\right)$ were studied three uses of ryegrass: (a) cover crop (CC), (b) silage (S) and (c) grazing of dairy heifers in integrated croplivestock (ICL). The ryegrass grown in ICL was grazed by dairy heifers (average stoking rate: $1200 \mathrm{~kg} \mathrm{ha}^{-1}$ ).

\section{Soil properties and Limestone}

The soil presented the following attributes [28] in the 0-20 cm layer, in 2009: 4.5, 107.0, 6.0, 29.0, 11.0 3.6 and $151.0 \mathrm{mmol}_{\mathrm{c}} \mathrm{kg}^{-1}$ of $\mathrm{pH}\left(\mathrm{CaCl}_{2}\right), \mathrm{H}+\mathrm{Al}, \mathrm{Al}^{3+}, \mathrm{Ca}^{2+}, \mathrm{Mg}^{2+}, \mathrm{K}^{+}$and cation exchange capacity (CEC), respectively; $20.9 \mathrm{mg} \mathrm{kg}^{-1}$ of $\mathrm{P}$ (Mehlich-1), $29 \%$ of soil base saturation (V); 463, 370 and $166 \mathrm{~g} \mathrm{~kg}^{-1}$ of clay, silt and sand, respectively. For soil acidity control was applied $8.36 \mathrm{Mg} \mathrm{ha}^{-1}$ of dolomitic limestone in March 
2009. The limestone dosage aimed to increase $\mathrm{V}$ to $70 \%$, value considered most suitable for maize production systems [8]. This limestone had 150, 250 and $740 \mathrm{~g} \mathrm{~kg}^{-1}$ of calcium oxide (CaO), magnesium oxide $(\mathrm{MgO})$ and effective calcium carbonate (ECC), respectively.

\section{Crops and Soil Sampling}

During 2009-14, ryegrass was cultivated followed by silage maize. The ryegrass harvested was FABC01 and the maize hybrids used were P30R50 and P32R22H (only in 2011/12 and 2012/13 crops) - being both simple hybrids. The input of nutrients via fertilizers during 2009-14 were of 2626; 695 and $1353 \mathrm{~kg} \mathrm{ha}^{-1}$ of nitrogen ( $\mathrm{N}$ ) (as urea), $\mathrm{P}_{2} \mathrm{O}_{5}$ (single superphosphate and triple superphosphate) and $\mathrm{K}_{2} \mathrm{O}$ (as potassium chloride), respectively. After the cutting of silage maize, soil samples were collected from layers $0-5,5-10$, 10-15, 15-20 and 20-30 cm with an auger sampler, at 24 and 60 months after liming. Twelve simple samples were collected from each layer and plot. In the laboratory, the samples were dried in an oven at $40{ }^{\circ} \mathrm{C}$ with forced air circulation for up to 48 hours, crushed and sifted $(2.0 \mathrm{~mm}$ mesh) and submitted the analytical determination performed according by [28]. The soil $\mathrm{pH}$ was determined in a $0.01 \mathrm{~mol} \mathrm{~L}^{-1} \mathrm{CaCl}_{2}$ solution using a 1:2.5 (v:v) soil-to-solution ratio suspension, and the $\mathrm{H}+\mathrm{Al}$ values were obtained after addition of SMP solution $(\mathrm{pH}=7.5)$, with measurement of the correspondent $\mathrm{pH}$ accomplished using a $\mathrm{pH}$ meter and glass electrode. Exchangeable-Al, $\mathrm{Ca}$, and $\mathrm{Mg}$ concentrations were ascertained in soil extracts obtained using a $1.0 \mathrm{~mol} \mathrm{~L}^{-1}$ potassium chloride $(\mathrm{KCl})$ solution, and titration using a $0.025 \mathrm{~mol} \mathrm{~L}^{-1}$ sodium hydroxide $(\mathrm{NaOH})$ solution for Al determination, and titration with ethylenediaminetetraacetic acid (EDTA) for $\mathrm{Ca}$ and Mg. While exchangeable-K concentrations were confirmed in soil extracts obtained using a Mehlich-1 $\left(0.05 \mathrm{~mol} \mathrm{~L}^{-1} \mathrm{HCl}\right.$ $+0.0125 \mathrm{~mol} \mathrm{~L}^{-1} \mathrm{H}_{2} \mathrm{SO}_{4}$ ) solution following readings by flame emission photometry. The $\mathrm{V}$ was calculated by the relationship between the exchangeable- $\mathrm{Ca}, \mathrm{Mg}$ and $\mathrm{K}$ values sum and $\mathrm{CEC}($ at $\mathrm{pH}=7.0)$ [19].

\section{Statistics}

All results were submitted to the sphericity test and it was observed that they met the H-F conditions [20] which made it possible to conduct univariate statistical analysis for each property under study in each layer $(0-5,5-10,10-15,15-20$ and $20-30 \mathrm{~cm})$. Conversion to the square root of the data was suggested regarding the values of $\mathrm{H}+\mathrm{Al}$ in the $0-5 \mathrm{~cm}$ layer and $\mathrm{V}$ at $15-20 \mathrm{~cm}$. Also suggested was the logarithmic conversion of the $\mathrm{H}+\mathrm{Al}$ data for the $10-15$ and $15-20 \mathrm{~cm}$ layers, as well as $\mathrm{V}$ at $20-30 \mathrm{~cm}$. The statistical model considered the following factors: four main treatments (CT, MT, NT and CNT); three secondary treatments (CC, S and $\mathrm{ICL}$ ); and soil chemical attributes in two evaluation periods (24 and 60 months after liming). In the absence of significant interaction, the following were considered: (i) as replications for soil management methods: blocks, uses of ryegrass, and soil chemical attributes evaluation periods; (ii) as replications for ryegrass usage: blocks, soil management methods, and soil chemical attributes evaluation periods; (iii) as replications for the soil chemical attributes evaluation periods: blocks, soil management methods, and usage of ryegrass. Regarding significant $F(P<0.05)$, averages were compared by using Tukey's test $(\alpha=0.05)$. All statistical analyses were carried out by employing the computer program SAS Version 9.2 [30].

\section{RESULTS}

Interactions were observed between the soil management methods, Italian ryegrass (ryegrass) usage, and evaluation periods of $\mathrm{pH}, \mathrm{H}+\mathrm{Al}$, exchangeable-aluminium (Al), and base saturation (V) in the five soil layers studied. Taking into consideration the soil management methods in each period under evaluation, at 24 months after liming, the NT and CNT presented higher $\mathrm{H}+\mathrm{Al}$ (Figure 1) and lower V (Figure 2) in the 10$15 \mathrm{~cm}$ layer. Exchangeable-Al (Figure 2) in CT was higher in the 0-5 cm layer and lower in the 20-30 cm layer. Additionally, in these layers exchangeable-Al (Figure 2) were not different for MT, NT and CNT.

At 60 months after liming, the CT experienced an increase in the $\mathrm{H}+\mathrm{Al}$ (Figure 1) and exchangeable-Al (Figure 2), with decrease in $\mathrm{pH}$ (Figure 1) and $\mathrm{V}$ (Figure 2) in the $0-5 \mathrm{~cm}$ layer. Increased pH (Figure 1) and decreased exchangeable Al (Figure 2) were noted in the NT at the $0-5 \mathrm{~cm}$ depth but did not differ from CNT regarding $\mathrm{H}+\mathrm{Al}$ (Figure 1) and $\mathrm{V}$ (Figure 2). In the remaining layers under study, the NT decreased the $\mathrm{pH}$, increased the $\mathrm{H}+\mathrm{Al}$ (Figure 1) and exchangeable-Al (Figure 2), with a decrease in V (Figure 2). The MT and CNT presented similar values of $\mathrm{pH}$ (Figure 1), of $\mathrm{H}+\mathrm{Al}$ (Figure 1) and of exchangeable-Al (Figure 2), as well as $V$ (Figure 2) in all layers under study except for the 5-10 cm layer, in which MT and NT presented lower exchangeable Al (Figure 2).

Regarding the effects of the different evaluation periods on the chemical attributes and soil management methods, 60 months after liming the NT demonstrated higher pH (Figure 1) and lower $\mathrm{H}+\mathrm{Al}$ (Figure 1) in the 
layer of 0-5 cm with lower exchangeable-Al (Figure 2) in the layer of 5-10 cm. However, from $5 \mathrm{~cm}$ depth on, a higher $\mathrm{V}$ (Figure 2) was observed 60 months after liming for all studied methods.

Comparing the uses of ryegrass in each period under evaluation, the ryegrass used as CC was noted to provide higher $\mathrm{pH}$ (Figure 1) and lower V (Figure 2) in the 0-5 cm layer 24 months after liming. The V (Figure 2) did not differ regarding uses of ryegrass in the layers of 5-10 and $15-20 \mathrm{~cm}$, but at 24 months after liming the ryegrass used as ICL presented lower $V$ in the layer of $10-15 \mathrm{~cm}$, and in the 20-30 cm layer with ryegrass used as CC and ICL the values were like each other except for lower $\mathrm{V}$. The uses of ryegrass presented higher $\mathrm{H}+\mathrm{Al}$ (Figure 1) in the layers of $0-5$ and $15-20 \mathrm{~cm}$ when observed in ICL. Also, ryegrass used as ICL and $\mathrm{CC}$ decreased exchangeable-Al (Figure 2) in the 10-15 cm layer, while reducing exchangeable-Al as ICL in the $20-30 \mathrm{~cm}$ layer (Figure 2). Similar results were attained with ryegrass usage in the remaining layers under study.

At 60 months after liming, the use of ryegrass produced similar results in the $0-5 \mathrm{~cm}$ layer, providing higher $\mathrm{pH}$ (Figure 1) and lower $\mathrm{H}+\mathrm{Al}$ (Figure 1) with a higher $\mathrm{V}$ (Figure 2). Differences in exchangeable-Al (Figure 2) were not observed in the $0-5 \mathrm{~cm}$ layer because of ryegrass usage. Also, the use of ryegrass did no difference in the $\mathrm{pH}$ (Figure 1) and $\mathrm{H}+\mathrm{Al}$ (Figure 1) in the 10-15 cm layer, and there were no differences observed in the $\mathrm{V}$ (Figure 2) in layers $5-10,10-15,15-20$ and $20-30 \mathrm{~cm}$. The ryegrass used as $\mathrm{S}$ did reduce exchangeable-Al (Figure 2) in layers $5-10$ and $10-15 \mathrm{~cm}$.

Considering the effect of evaluation periods which impacted chemical attributes with the usage of ryegrass. At 60 months after liming, ryegrass used as CC produced an increase in the pH (Figure 1) and a decrease in the $\mathrm{H}+\mathrm{Al}$ (Figure 1) in all layers analyzed. The ryegrass used as $\mathrm{S}$ and ICL did not, over time, changes in the $\mathrm{pH}$ (Figure 1), but did reduce the $\mathrm{H}+\mathrm{Al}$ (Figure 1) in all layers under study. All ryegrass usage was efficient in the decrease of exchangeable-Al (Figure 2) in the $0-5 \mathrm{~cm}$ layer at 24 months after liming but did not result in differences between the periods under evaluation for the remaining layers. The usage of ryegrass 60 months after liming also increased V (Figure 2) in the layers under study, except for the $0-5 \mathrm{~cm}$ layer in which ryegrass used as $S$ did not show any difference between the periods under evaluation.

Analyses of each use of ryegrass in each soil management method confirmed that there was no difference between ryegrass usage in any of the soil management methods in any of the layers under study regarding $\mathrm{pH}$ (Figure 3). However, only in the $0-5 \mathrm{~cm}$ layer there was difference between the usage of ryegrass with CT and CNT, and MT and NT, methods, with the usage of ryegrass as $S$ and ICL producing similar $\mathrm{H}+\mathrm{Al}$ (Figure 4). Also, in this layer in CT the usage of ryegrass as $\mathrm{S}$ and ICL provided higher exchangeable-Al followed by CC, and in NT the use of ryegrass as CC and ICL resulted in higher exchangeable-Al (Figure 5). Additionally, in the $5-10 \mathrm{~cm}$ layer in MT and CNT with ryegrass usage as CC and S, higher exchangeable-Al were observed (Figure 5), while in the 20-30 cm layer in NT and CNT there were higher and lower exchangeable Al with the use of ryegrass as ICL and S, respectively (Figure 5). Only in the $0-5 \mathrm{~cm}$ layer did the usage of ryegrass as CC in CT provide higher V (Figure 6).

Upon examination of each soil management method with each use of ryegrass, it was confirmed that in the 0-5 cm layer, all ryegrass uses produced higher $\mathrm{pH}$ in MT and CNT (Figure 3). In the 10-15 and 15-20 $\mathrm{cm}$ layers when ryegrass was used as $\mathrm{CC}$, there were higher $\mathrm{H}+\mathrm{Al}$ with the NT and CNT methods, followed by MT and CT. Only in the 10-15 cm layer when ryegrass was used as $S$ and ICL were higher $\mathrm{H}+\mathrm{Al}$ seen in $\mathrm{NT}$, and lower $\mathrm{H}+\mathrm{Al}$ values in $\mathrm{CT}$, respectively (Figure 4). In the $0-5 \mathrm{~cm}$ layer when ryegrass was used as $\mathrm{S}$ and ICL, lower and higher exchangeable-Al were observed in NT and CT, respectively (Figure 5). In the 5$10,10-15$, and $15-20 \mathrm{~cm}$ layers when ryegrass was used as $\mathrm{CC}$ and ICL, higher exchangeable-Al was observed in NT and CNT, followed by CT and MT (Figure 5). In the 20-30 cm layer when ryegrass was used as $S$ and ICL, higher exchangeable-Al was observed in NT, followed by MT, CNT, and CT (Figure 5). An increase in $\mathrm{V}$ was observed in NT and CNT, followed by MT and CT, when ryegrass was used as CC and $I C L$, while there was a decrease in $V$ when ryegrass was used as $S$ and $C T$ in the $0-5 \mathrm{~cm}$ layer (Figure 6). In the 5-10 cm layer when ryegrass used as CC, higher $V$ was observed in CT and MT, followed by CNT and NT, and when the ryegrass used as $S$ and ICL, there was increase of V in MT and CNT, followed by CT and MT (Figure 6). In the 10-15 and $15-20 \mathrm{~cm}$ layers for all uses of ryegrass, there was an increase of $\mathrm{V}$ in MT and CT, followed by CNT and NT (Figure 6). 


\section{0-5 cm layer}

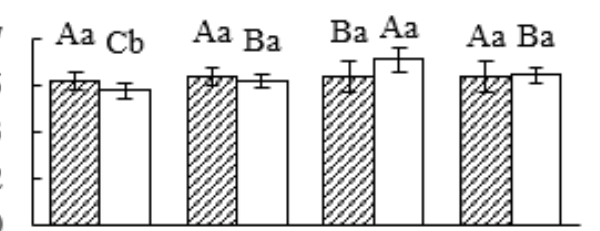

\section{$5-10 \mathrm{~cm}$ layer}

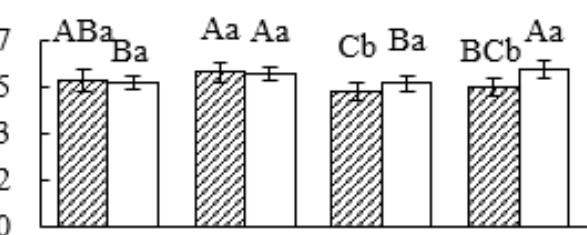

\section{$10-15 \mathrm{~cm}$ layer}

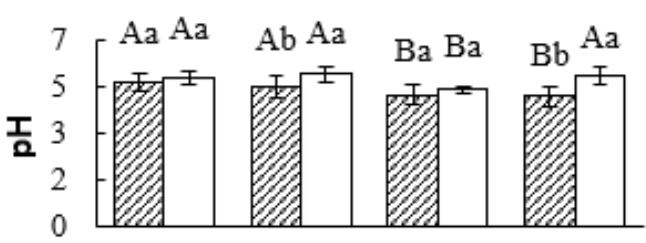

$15-20 \mathrm{~cm}$ layer

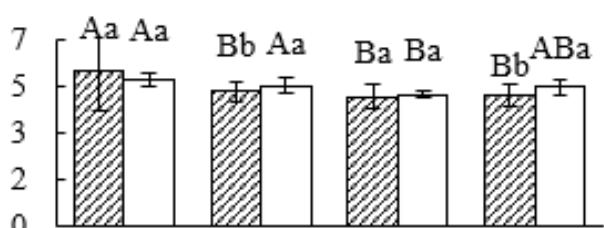

\section{0-30 cm layer}

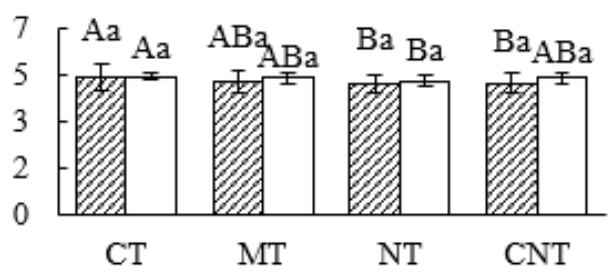

\section{Soil management methods}
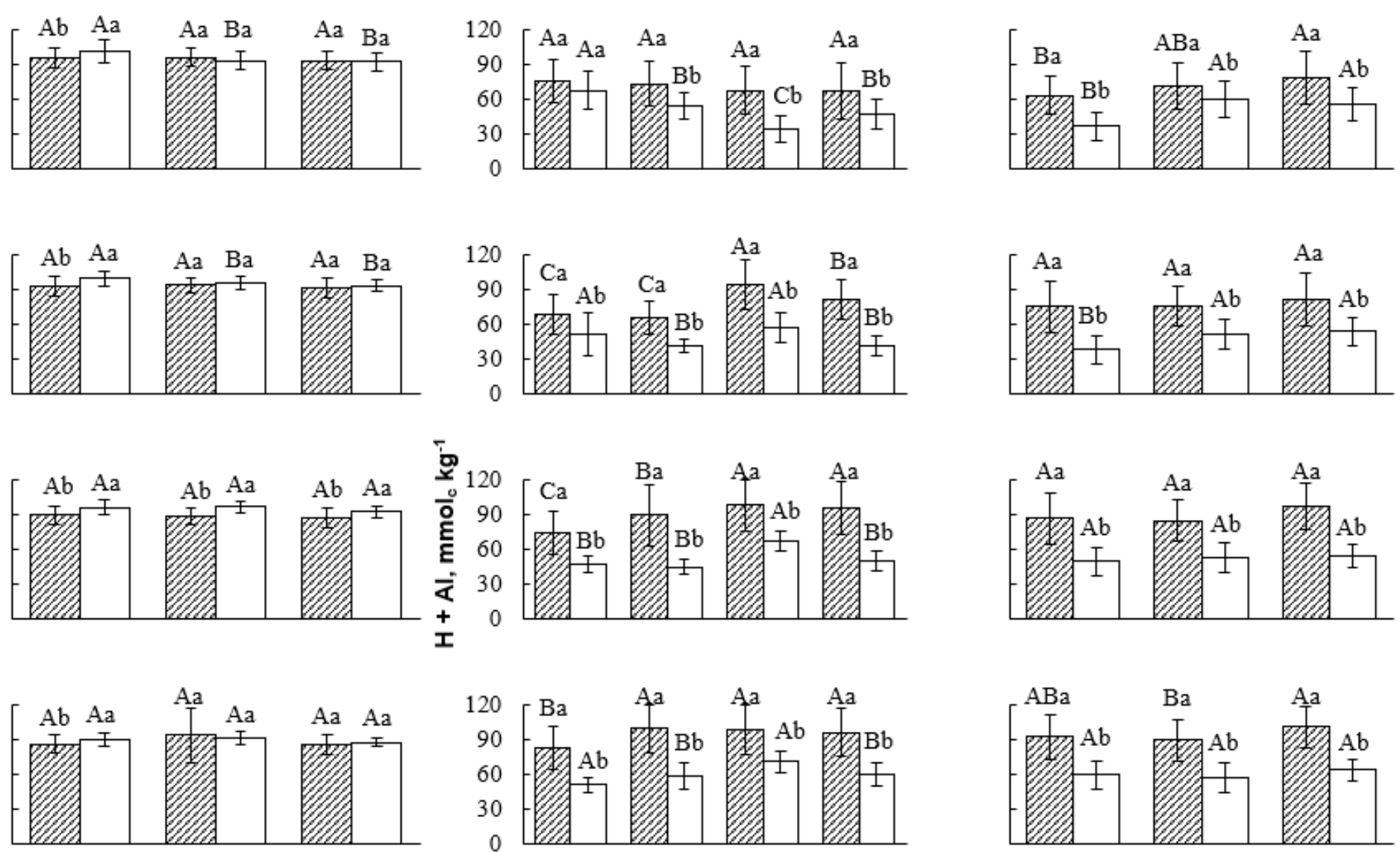

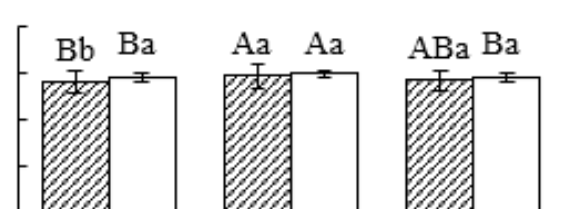

$\mathrm{CC}$
Uses of 1

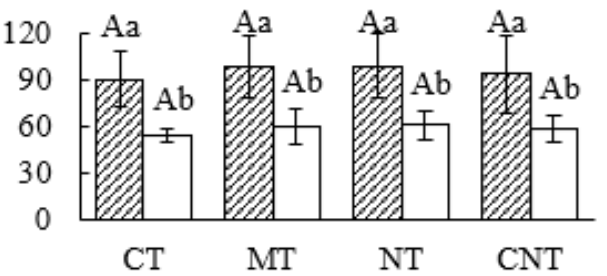

Soil management methods

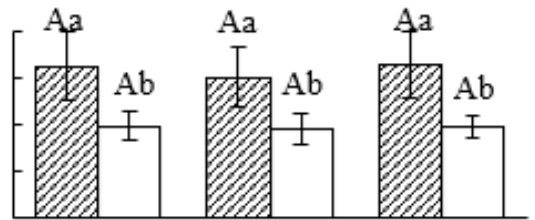

$\mathrm{CC}$

Figure 1. Values of $\mathrm{pH}\left(0.01 \mathrm{~mol} \mathrm{~L}^{-1}\right.$ calcium chloride solution) and of $\mathrm{H}+\mathrm{Al}$ at $24(/ /)$ and $60(\square)$ months after liming (and throughout five silage maize crops) ( $n=12 \pm$ standard deviation) in each soil management method [conventional tillage (CT), minimum tillage (MT), no-till (NT) and chiseled no-till (CNT)] and in each use of Italian ryegrass [cover crop $(C C)$, silage $(S)$, and grazing of dairy heifers in integrated crop-livestock $(I C L)]$. Averages followed by same capital letters did not differ statistically in Tukey's test $(\alpha=0.05)$ regarding soil management methods and uses of Italian ryegrass in each period under study. Averages followed by the same small letters did not differ statistically in Tukey's test $(\alpha=0.05)$ for the periods of soil attribute evaluation in each soil management method and in each use of Italian ryegrass. 


\section{$0-5 \mathrm{~cm}$ layer}
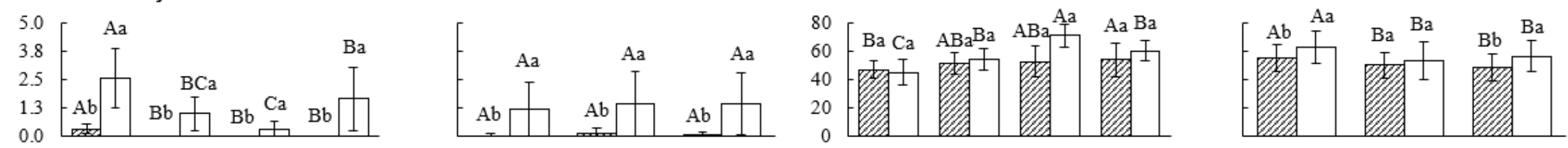

$5-10 \mathrm{~cm}$ layer
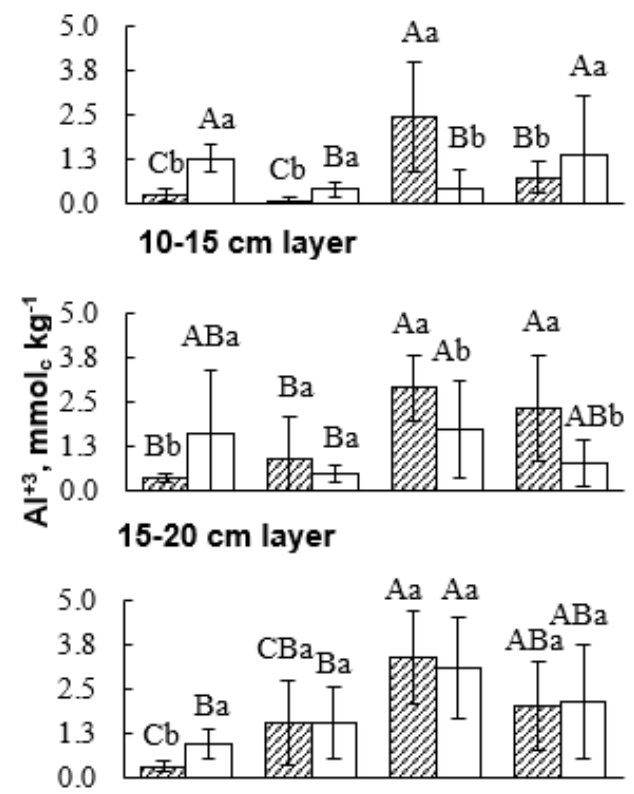

\section{$20-30 \mathrm{~cm}$ layer}

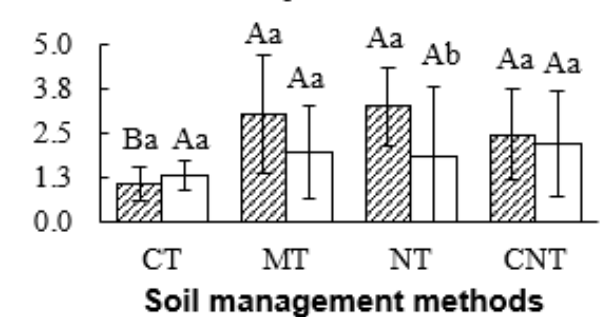

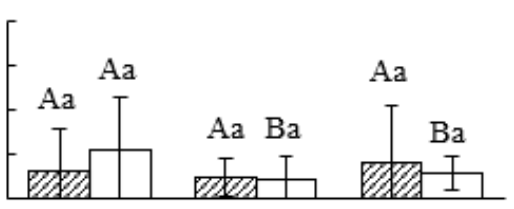
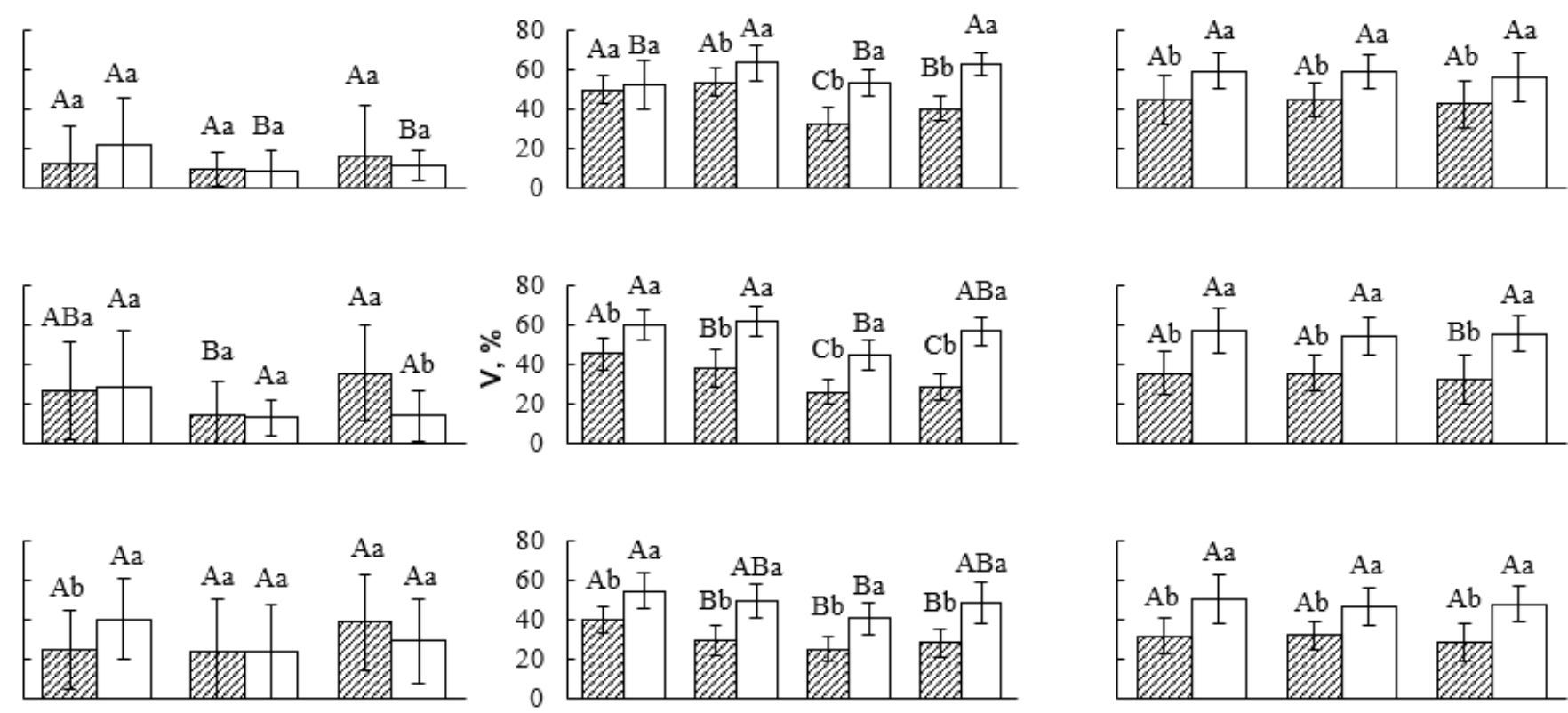

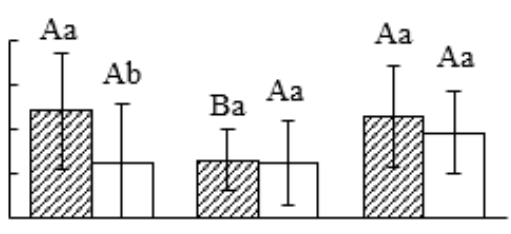

$\mathrm{CC}$
ICL

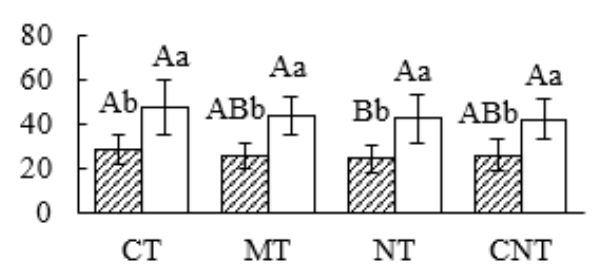

Soil management methods

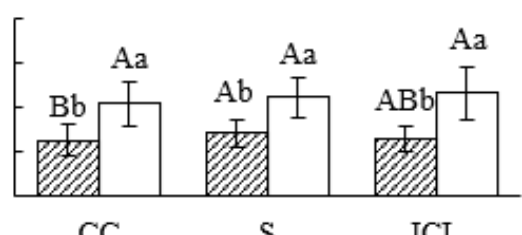

Uses of Italian ryegrass

Figure 2. Exchangeable aluminum $(\mathrm{Al}+3)$ and Soil base saturation $(\mathrm{V})$ at $24(\mathbb{Z})$ and $60(\square)$ months after liming (and throughout five silage maize crops) $(n=12 \pm$ standard deviation) in each soil management method [conventional tillage (CT), minimum tillage (MT), no-till (NT), and chiseled no-till (CNT)] and in each use of Italian ryegrass [cover crop (CC), silage $(S)$, and grazing of dairy heifers in integrated crop-livestock $(I C L)]$. Averages followed by same capital letters did not differ statistically in Tukey's test $(\alpha=0.05)$ regarding soil management methods and uses of Italian ryegrass in each period under study. Averages followed by the same small letters did not differ statistically in Tukey's test $(\alpha=0.05)$ for the periods of soil attribute evaluation in each soil management method and in each use of Italian ryegrass. 


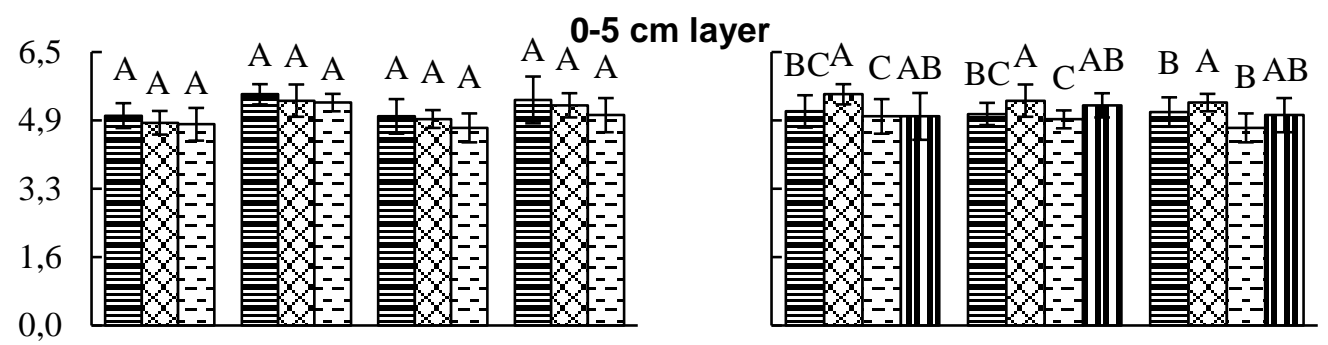

\section{5-10 cm layer}
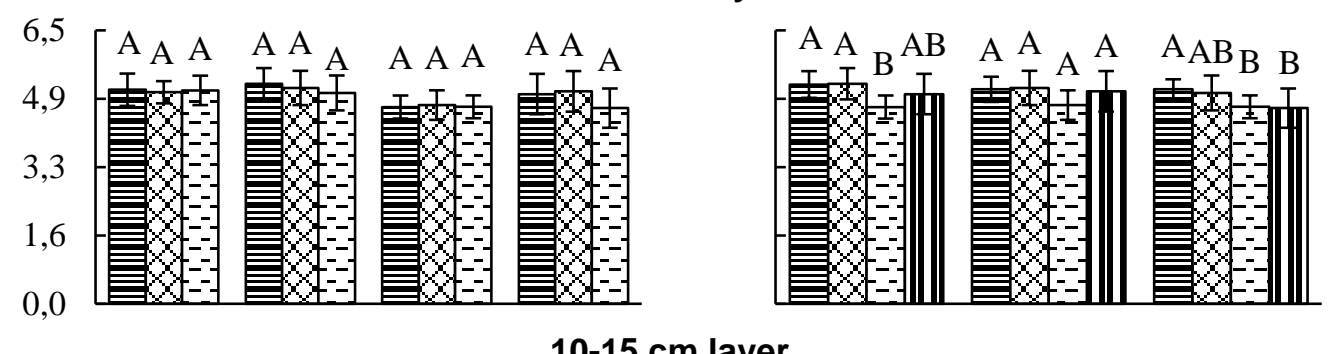

10-15 cm layer
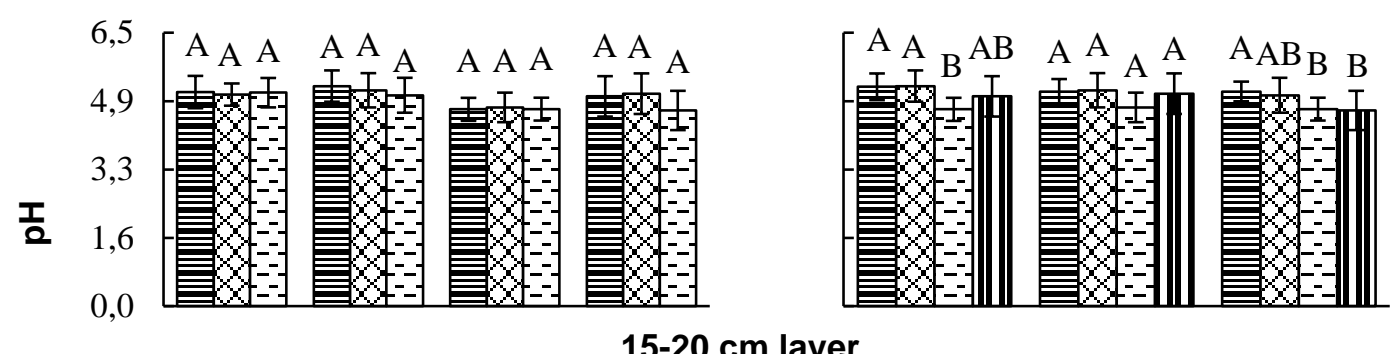

$15-20 \mathrm{~cm}$ layer
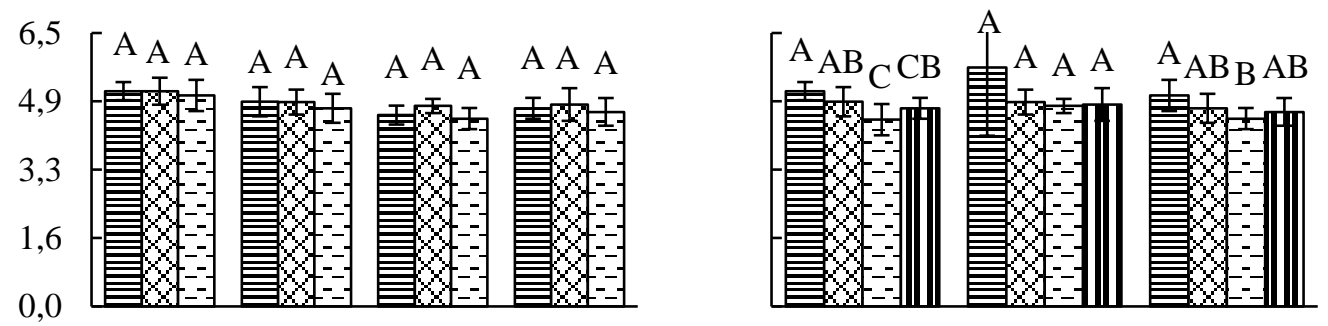

20-30 cm layer
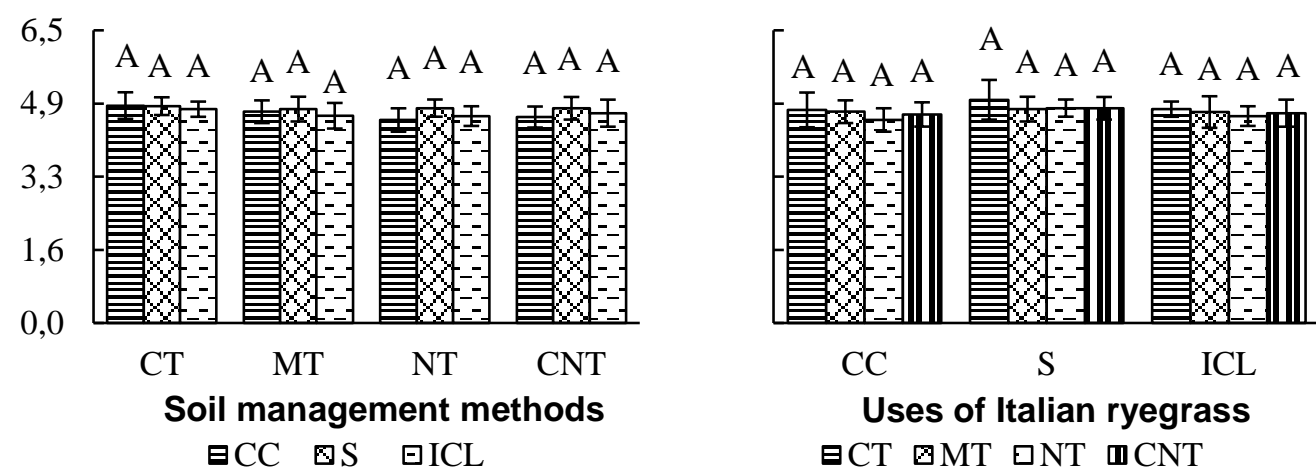

Figure 3. Values of $\mathrm{pH}$ (in $0.01 \mathrm{~mol} \mathrm{~L}^{-1}$ calcium chloride solution) throughout five silage maize crops ( $n=8 \pm$ standard deviation) in each soil management method [conventional tillage (CT), minimum tillage (MT), no-till (NT), and chiseled no-till (CNT)] and in each use of Italian ryegrass [cover crop (CC), silage (S), and grazing of dairy heifers in integrated crop-livestock (ICL)]. Averages followed by the same letters did not differ statistically in Tukey's test $(\alpha=0.05)$ in each soil management method and in each use of Italian ryegrass. 


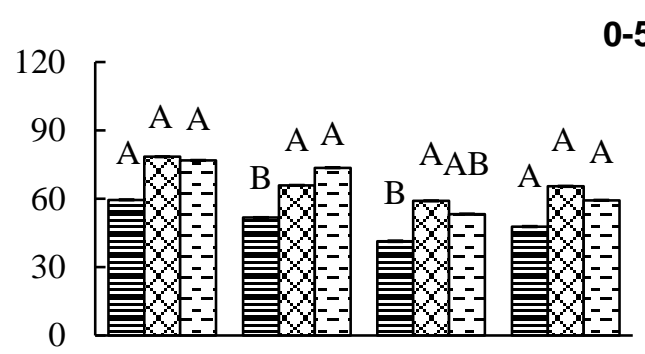

0-5 cm layer

\section{5-10 cm layer}
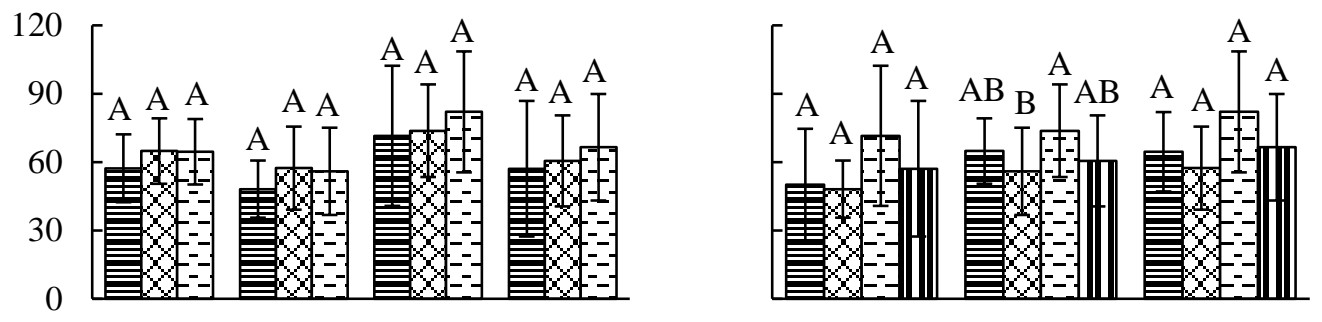

10-15 cm layer
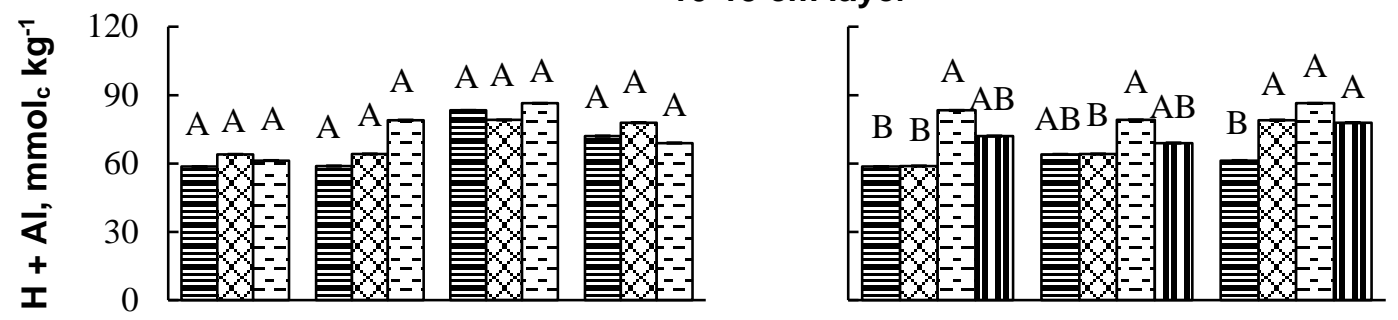

$15-20 \mathrm{~cm}$ layer
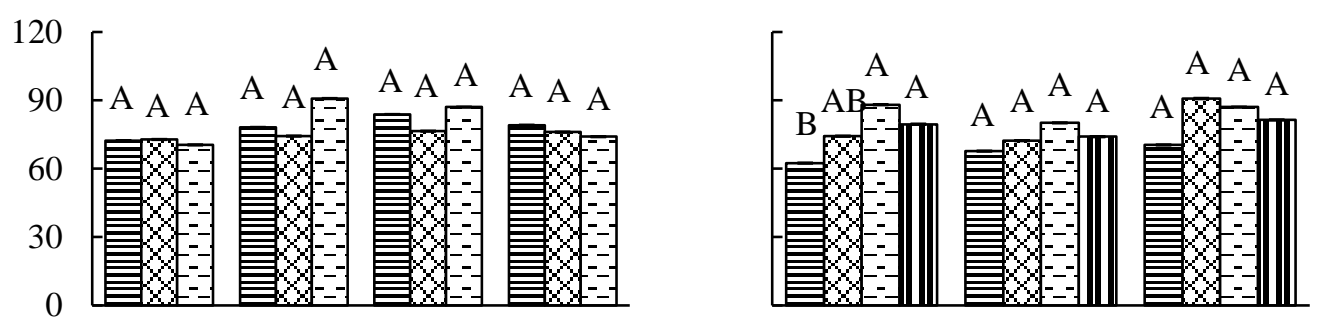

\section{0-30 cm layer}
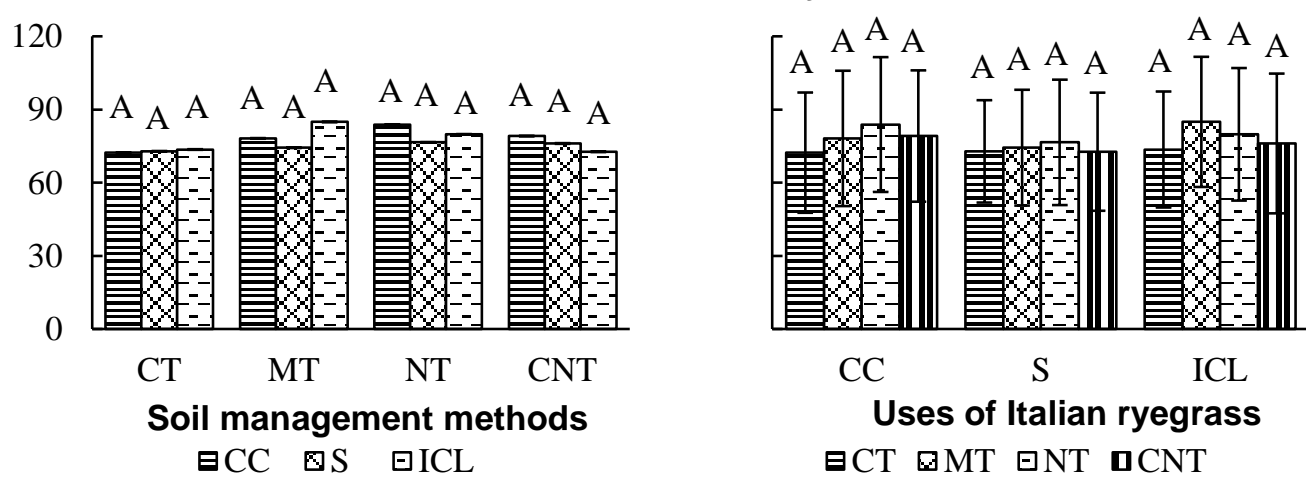

Figure. 4. Values of $\mathrm{H}+\mathrm{Al}$ throughout five silage maize crops ( $\mathrm{n}=8 \pm$ standard deviation) in each soil management method [conventional tillage (CT), minimum tillage (MT), no-till (NT), and chiseled no-till (CNT)] and in each use of Italian ryegrass [cover crop (CC), silage (S), and grazing of dairy heifers in integrated crop-livestock (ICL)]. Averages followed by the same letters did not differ statistically in Tukey's test $(\alpha=0.05)$ in each soil management method and in each use of Italian ryegrass. 


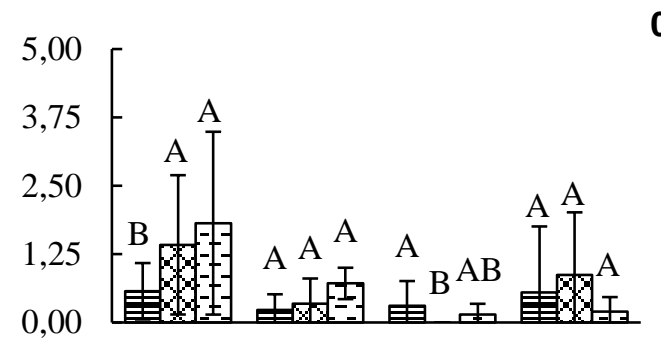

$0-5 \mathrm{~cm}$ layer

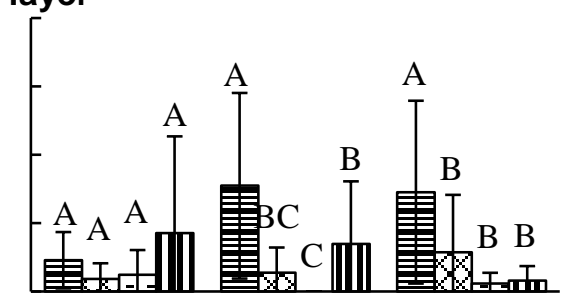

\section{5-10 cm layer}
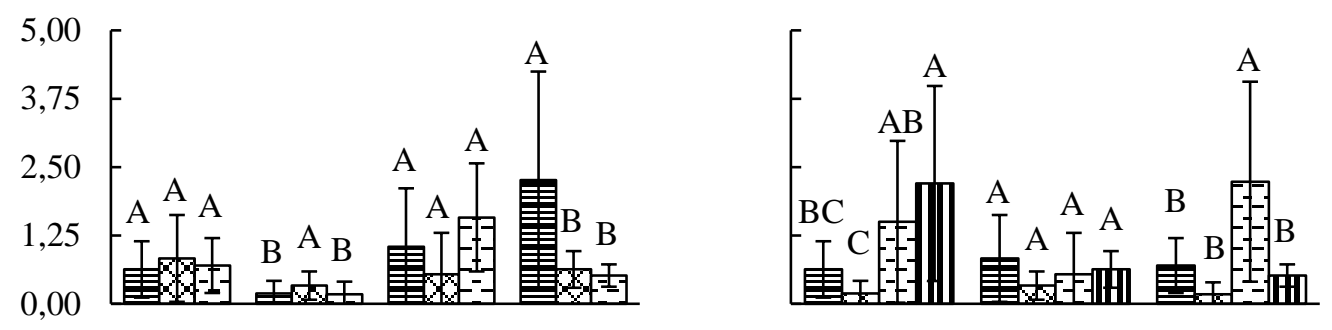

$10-15 \mathrm{~cm}$ layer
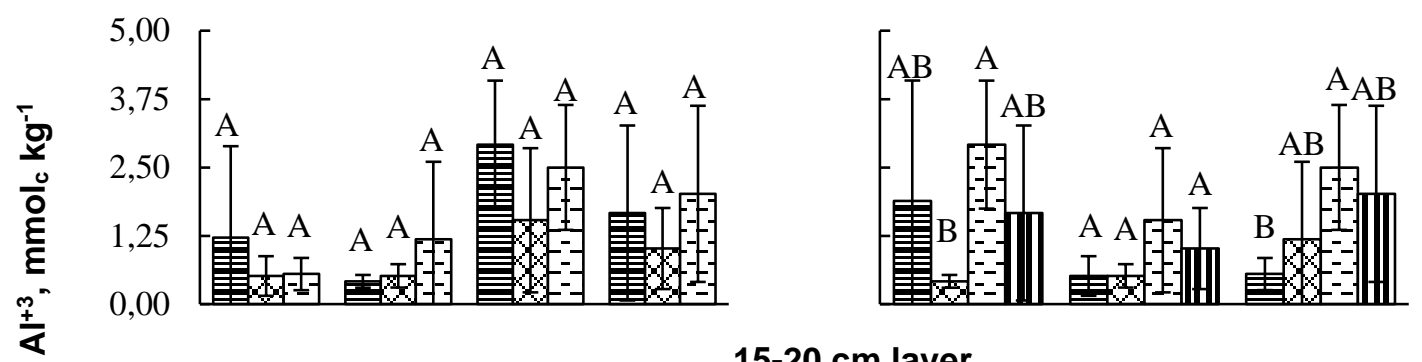

$15-20 \mathrm{~cm}$ layer
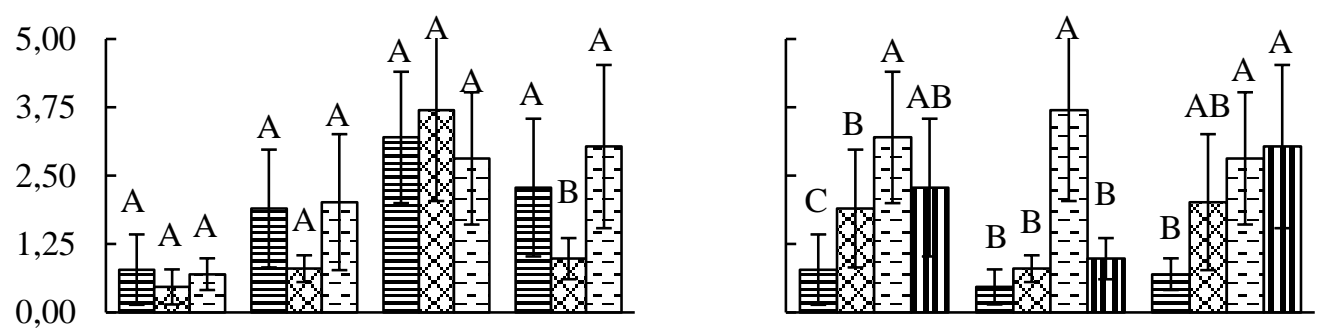

20-30 cm layer
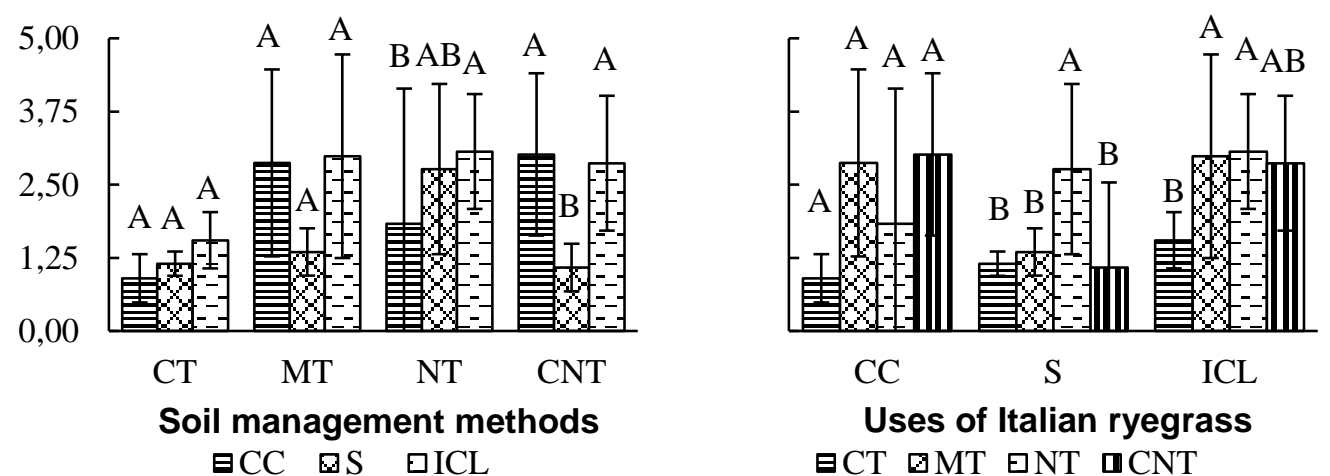

Figure 5. Exchangeable aluminum ( $\left.\mathrm{Al}^{3+}\right)$ throughout five silage maize crops $(\mathrm{n}=8 \pm$ standard deviation) in each soil management method [conventional tillage (CT), minimum tillage (MT), no-till (NT), and chiseled no-till (CNT)] and in each use of Italian ryegrass [cover crop (CC), silage (S), and grazing of dairy heifers in integrated crop-livestock (ICL)]. Averages followed by the same letters did not differ statistically in Tukey's test $(\alpha=0.05)$ in each soil management method and in each use of Italian ryegrass. 


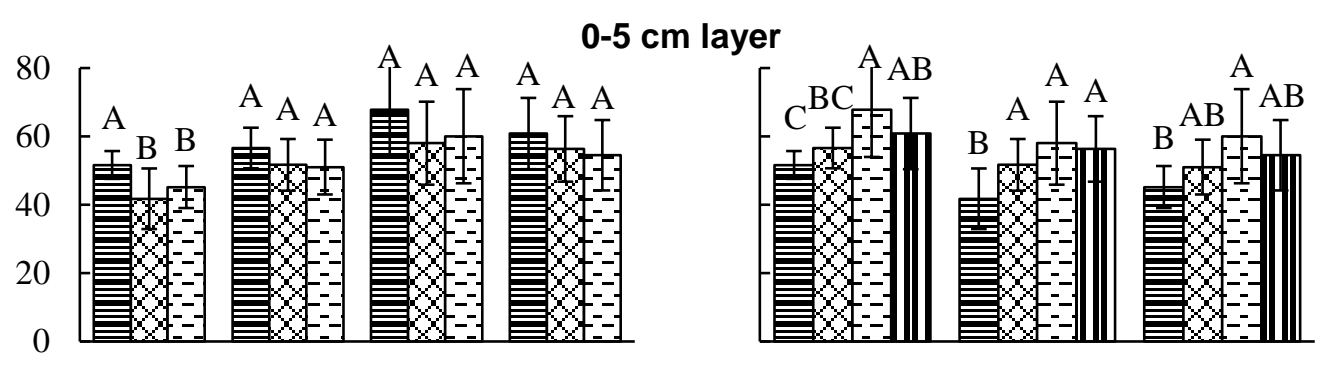

$5-10 \mathrm{~cm}$ layer
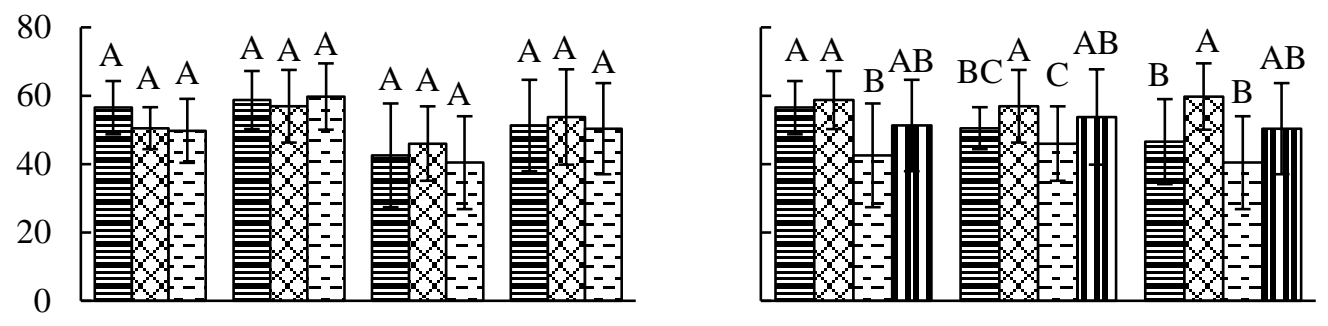

10-15 cm layer
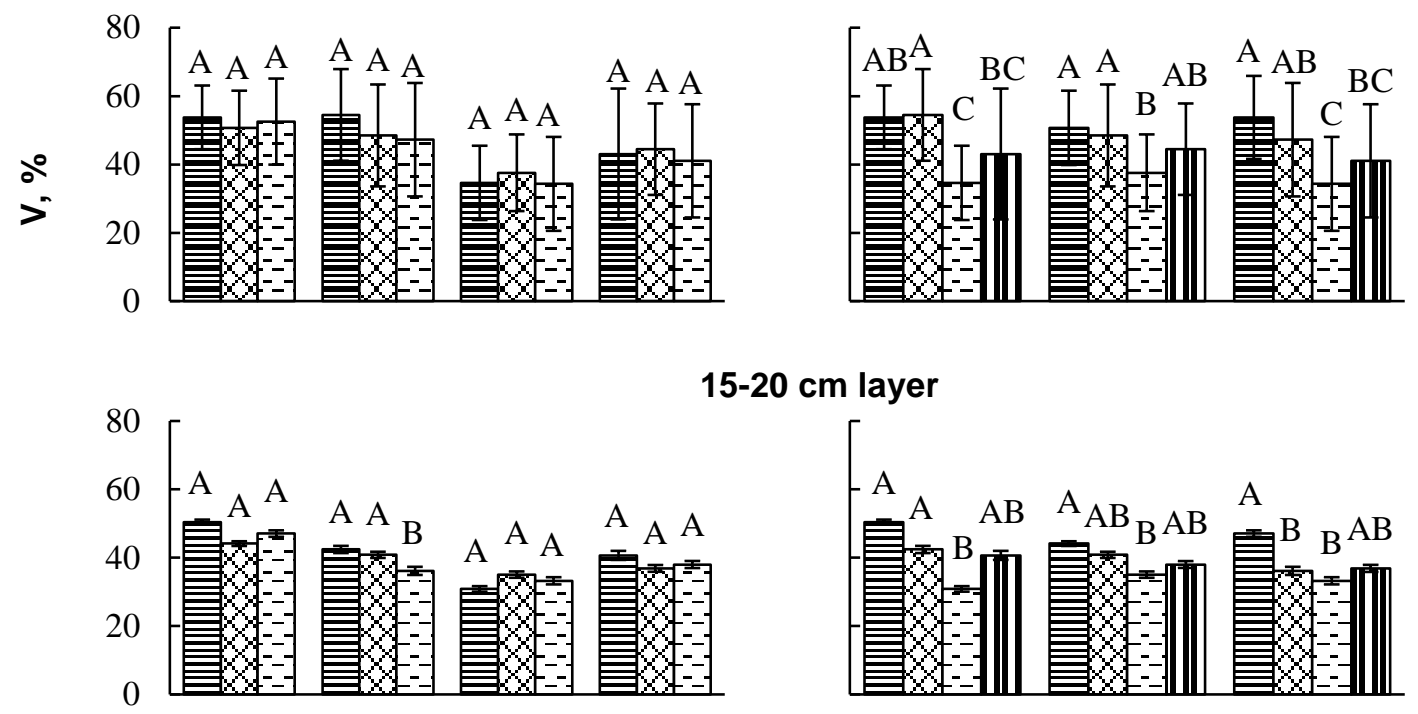

\section{0-30 cm layer}
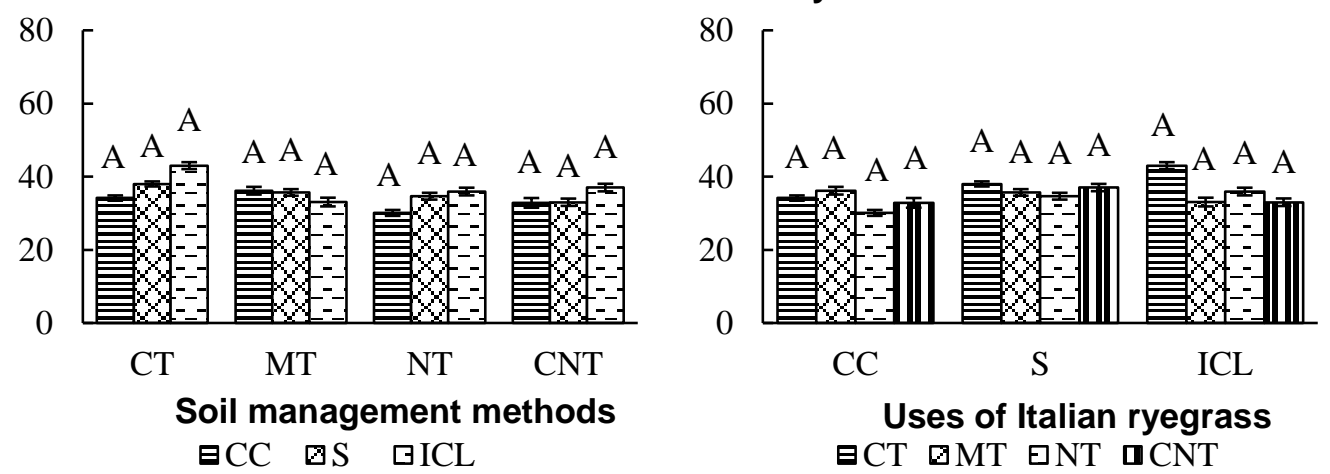

Figure 6. Soil base saturation (V) throughout five silage maize crops ( $n=8 \pm$ standard deviation) in each soil management method [conventional tillage (CT), minimum tillage (MT), no-till (NT), and chiseled no-till (CNT)] and in each use of Italian ryegrass [cover crop (CC), silage (S), and grazing of dairy heifers in integrated crop-livestock (ICL)]. Averages followed by the same letters did not differ statistically in Tukey's test $(\alpha=0.05)$ in each soil management method and in each use of Italian ryegrass. 


\section{DISCUSSION}

The dynamics and variability of soil acidity tend to persist in agriculture for hundreds of years [16], especially in production systems that use pasture, grain crops and/or silage, and nitrogen fertilizers, such as ICL, where soil acidification is continuous during and after liming $[6,26]$. Exchangeable-Al is the main limiting factor in acid soils which can present a barrier to achieving improvements in plant yield $[14,15]$. Therefore, liming which serves to increase $\mathrm{pH}$, reduce $\mathrm{H}+\mathrm{Al}$ and exchangeable-Al and increase $\mathrm{V}$, can in turn lead to an increase in plant yield.

In the short-term (up to 24 months), management methods (Figure 1 to 6 ) that turn the soil to optimize the limestone reaction, such as CT, are efficient to increase $\mathrm{pH}$ within the $0-20 \mathrm{~cm}$ depth. In others study, also observed acidity decreases in deeper layers $(<20 \mathrm{~cm})$ when the soil was turned with limestone [14]. In this study, turning the soil might have favored the physical migration of limestone and the incorporation of organic material into the soil up to $30 \mathrm{~cm}$, increasing $\mathrm{pH}$ values while decreasing $\mathrm{H}+\mathrm{Al}$ and exchangeable-Al. However, it is an unsuitable practice in conservation agriculture due to carbon loss by the soil [18]. In the medium-term (a period between 5-25 years), NT has demonstrated the ability to control soil acidity, not only in the superficial layer $(0-5 \mathrm{~cm})$, but also in the part-soil surface layer $(0-20 \mathrm{~cm})$ where the primary root system is located [13]. This outcome might be a result of increased buffering that originates from the higher content

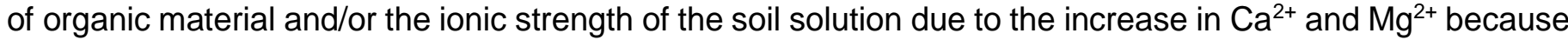
of surface liming. In addition, NT and CNT do not present differences regarding soil acidity values, indicating that CNT might be disregarded in soils with high organic matter content, such as the one in this study. Such elimination of CNT in this situation could also provide production system cost benefits with fewer tractor hours required and decreased organic soil material depletion.

When Italian ryegrass (ryegrass) is used as $S$ and ICL, it might release organic compounds due to the intense exploitation of the aerial and root parts in a homogeneous and constant way throughout time [11]. In others study, observed changes in soil $\mathrm{pH}$ due to the intense production of roots and exudates of grazed forage [9]. Further, when ryegrass is incorporated in ICL, the increased organic matter in the soil coming from plant and animal (feces and urine) residues might release organic compounds (carboxyl and phenolic groups) [21], and these residues could lead to the complexation of $\mathrm{Al}^{3+}$ (with release of $\mathrm{OH}^{-}$), as well as the release of $\mathrm{Ca}^{2+}$ and $\mathrm{Mg}^{2+}$, facilitating soil cation redistribution and soil acidity decrease [24]. Therefore, in ICL allied with NT, the dissolution of limestone and subsequent improvement in soil acidity might occur over time due to: (i) an increase in organic matter coming from vegetable and animal residue; (ii) intense application of nitrogen fertilizer [19] when ryegrass is used as $S$ and ICL in order to ensure exploitation of the crop by the animal; (iii) physical migration and vertical movement of the limestone fine particles [1] through the biopores [2] formed as a result of the root system constant renewal [11]; and also, (iv) formation and migration of Ca and $\mathrm{Mg}$ bicarbonates [27]. Therefore, animal grazing in ICL can increase $\mathrm{pH}$ in the short-term or long-term (11 years) [23].

NT and ryegrass used as $C C$ on the surface $(0-5 \mathrm{~cm}$ layer) were the most efficient methods of maintaining a high $\mathrm{V}$ over time but produced a smaller increase in $\mathrm{V}$ beyond the soil surface when compared to the remaining soil management methods with ryegrass usages (Figure 1 to 6 ). Liming increased the $V$ up to the 10-cm layer when limestone was superficially applied [17]. This fact might be ascribed to the higher vertical variability of soil fertility in NT where there is greater heterogeneity of soil acidity in deep layers $(10-30 \mathrm{~cm})$. Also, ryegrass used as CC is capable of nutrient uptake from deep layers and, after biomass drying, the nutrients may be released in the $0-5 \mathrm{~cm}$ layer, increasing the $\mathrm{V}$.

Only in NT and ICL in the $0-5 \mathrm{~cm}$ layer were there observed values of $\mathrm{V}$ approaching $70 \%$ (V aimed) (Figure 1 to 6). Ryegrass used as $S$ and ICL was associated with lower $V$ in the $0-5 \mathrm{~cm}$ layer due to intense exportation of basic soil cations $(\mathrm{Ca}, \mathrm{Mg}$, and $\mathrm{K})$ by the crops, higher nitrogen uptake $(\mathrm{N})$ via fertilizers and, consequently, proton $\left(\mathrm{H}^{+}\right)$release due to the nitrogen process that influences $\mathrm{pH}$ values and $\mathrm{V}$ [19]. This activity might benefit limestone dissolution and cation redistribution in the soil; however, it will lead to an increase in acidity and a decrease in V. In addition, the presence of animals in ICL will increase the liming effects and smooth acidity variability, as well as V, up to $30 \mathrm{~cm}$ of soil depth. In addition, the liming residual effect could persist for up to 60 months after being applied in production systems with silage maize and ryegrass once suitable crop and soil management methods incorporating limestone and fertilizers are employed under favorable climate conditions. The findings from this 60-month study differ from those of [31] conducted in Oxisol and NT where a soil maximum increase in V was observed at 25 and 24 months after liming, respectively, but involved a major presence of gaseous leguminous plants over a shorter term. 


\section{CONCLUSION}

The no-tillage method and use of Italian ryegrass as cover crop were the most efficient methods for increasing the $\mathrm{pH}$ of soil, reducing $\mathrm{H}+\mathrm{Al}$ values and exchangeable aluminium, and improving base saturation only in the $0-5 \mathrm{~cm}$ layer. These effects were more evident 60 months after liming. Additionally, regarding acidity control and increased base saturation, chiselled should be avoided in no-tillage. The Italian ryegrass used as silage and for animal grazing in integrated crop-livestock systems with no-tillage provided higher $\mathrm{pH}$ values and lower $\mathrm{H}+\mathrm{Al}$ values in the $10-30 \mathrm{~cm}$ layer. Over time, the Italian ryegrass uses favoured liming with a positive residual effect persisting for up to 60 months after application in silage maize and Italian ryegrass production systems regardless of the type of Italian ryegrass use, whether for animal grazing or as silage. Therefore, the use of Italian ryegrass during winter should be further explored for its potential to offer greater benefits at deep soil levels than cover crops.

Acknowledgments: The authors would like to express gratitude for the support received from CNPq, CAPES, and Fundação ABC, and for the use of the C-LABMU/PROPESP/UEPG.

Conflicts of Interest: The authors declare no conflict of interest.

\section{REFERENCES}

1. Amaral AS, Anghinoni I, Hinrichs R, Bertol I. (2004) Movimentação de partículas de calcário no perfil de um Cambissolo em plantio direto. Rev Bras Ciên Solo. 2004 (28):359-67.

2. Auler AC, Miara S, Pires LF, Da Fonseca AF, Barth G. Soil physico-hydrical properties resulting from the management in integrated production systems. Rev Ciên Agron. 2014 (45):976-89.

3. Balbinot Junior AA, Moraes A, Veiga M, Pelissari A, Dieckow J. Integração lavoura-pecuária: intensificação de uso de áreas agrícolas. Ciên Rural. 2009(39):1925-33.

4. Bolan NS, Hedley MJ. The role of carbon, nitrogen and sulphur in soil acidification. In 'Handbook of Soil Acidification.' (Ed Z. Rengel) pp. 29-56. (Marcel Dekker, New York), 2003.

5. Bolan NS, Rowarth J, De La Luz Mora M, Adriano D, Curtin D. Biological transformation and bioavailability of nutrient elements in acid soils as affected by liming. Developments in Soil Science 32 (Ed Ravendra Naidu), 2008.

6. Bolland MDA, Russell WK. Changes in chemical properties of 48 intensively grazed, rain-fed dairy paddocks on sandy soils over 11 years of liming in south-western Australia. Austr J Soil Res 2010 (48):682-92.

7. Bolliger A, Magid J, Amado TJC, Skóra Neto F, Ribeiro MFS, Calegari A, Ralisch R, Neergaard A. Taking stock of the Brazilian "zero-till revolution": a review of landmark research and farmers' practice. Advances Agron 2006 (91):1-64.

8. Caires EF, Alleoni LRF, Cambri MA, Barth G. Surface application of lime for crop grain production under a no-till system. Agron J 2005 (97):791-8.

9. Carvalho PCF, Anghinoni I, Kunrath TR, Martins AP, Costa SEVGA, Damian FS, Assmann JM, Lopes MLT, Pfeifer FM, Conte O, Souza 'Integração soja-bovinos de corte no Sul do Brasil' (Gráfica RJR, Porto Alegre) 2011.

10.Cecagno D, Costa SEVGA, Anghinoni I, Kunrath TR, Martins AP, Reichert JM, Gubiani PI, Balerini F, Fink JR, Carvalho PCF. Least limiting water range and soybean yield in a long-term, no-till, integrated crop-livestock system under different grazing intensities. Soil Till Res 2016 (156):54-62.

11.Dos Santos JA, Da Fonseca AF, Barth G, Zardo Filho, R. Silage maize quality in diferente uses of Italian ryegrass and soil management methods adter liming. Arch Agron Soil Sci 2017 (64):173-84.

12. Falleiro RM, Souza CM, Silva CSW, Sediyama CS, Silva AA, Fagundes JL. Influência dos sistemas de preparo nas propriedades químicas e físicas do solo. Rev Bras Ciênc Solo 2003 (27):1097-104.

13.Fante Jr L, Reichardt K, Jorge LAC, Crestana S. Distribuição do sistema radicular do milho em terra roxa estruturada latossólica: I. Comparação de metodologias. Scientia Agricola 1994 (51):513-8.

14.Frankowski M, Zioła-Frankowska A, Siepak J. From soil to leaves - aluminum fractionation by single step extraction procedures in polluted and protected areas. J Envir Manag 2013 (127):1-9.

15.Frankowski M, Zioła-Frankowska A, Siepak J. Speciation of aluminum fluoride complexes and $\mathrm{Al}^{3+}$ in soils from the vicinity of an aluminum smelter plant by hyphenated high performance ion chromatography flame atomic absorption spectrometry technique. Microch J 2010 (95):366-72.

16. Fraser MA, Scott BJ Variability of acidity in agricultural soils - the impact of timber burning at land clearing. Aust $\mathrm{J}$ Soil Res 2011 (49):223-30.

17.Freiria AC, Mantovani JR, Ferreira ME, Cruz MCP, Yagi R. Alterações em atributos químicos do solo pela aplicação de calcário na superfície ou incorporado. Acta Scient Agron 2008 (30):285-91. 
18. Freixo AA, Machado PLOA, Guimarães CM, Silva CA, Fadigas FS. Estoques de carbono e nitrogênio e distribuição de frações orgânicas de Latossolo do cerrado sob diferentes sistemas de cultivo. Rev Bras Ciênc Solo 2002 (26):425-34.

19. Havlin JL, Tisdale SL, Nelson WL, Beaton JD. Soil fertility and fertilizers: an introduction to nutrient management. Uper Sadle River: NJ. Pearson. 2014.

20. Huynh H, Feldt LS. Conditions under which mean square rations in repeated measurements designs have exact F-distributions. J Amer Statist Assoc 1970 (65):1582-9.

21.Ma JF, Ryan PR, Delhaize E. Aluminum tolerance in plants and the complexing role of organics acids. Trends Plant Science 2001 (6):273-8.

22. Martins AP, Anghinoni I, Costa SEVGA, Carlos FS, Nichel GH, Silva RAP, Carvalho PCF. Amelioration of soil acidity and soybean yield after surface lime reapplication to a long-term no-till integrated crop-livestock system under varying grazing intensities. Soil Till Res 2014 (144);141-9.

23. Martins AP, Cecagno D, Borin JBM, Arnuti F, Lochmann SH, Anghinoni I, Bissani CA, Bayer C, Carvalho PCF. Long-, medium- and short-term dynamics of soil acidity in an integrated crop-livestock system under different grazing intensities. Nutr Cyc Agroecos 2016 (104):67-77.

24. Miyazawa M, Pavan MA, Calegari A. Efeito de material vegetal na acidez do solo. Rev Bras Ciênc Solo 1993 (17):411-6.

25. Moraes A, Carvalho PCF, Anghinoni I, Lustosa SBC, Costa SEVGA, Kunrath RR. Integrated crop-livestock systems in the Brazilian subtropics. Europ J Agron 2014 (57):4-9.

26. Noble AD, Suzuki S, Soda W, Ruaysoongnern S, Berthelsen S. Soil acidification and carbon storage in fertilized pastures of Northeast Thailand. Geoderma 2008 (144):248-55.

27. Oliveira EL, Pavan MA. Control of soil acidity in no-tillage system for soybean production. Soil Till Res 1996 (38):4757.

28.Pavan MA, Bloch MF, Zempulski HC, Miyazawa M, Zocoler DC. Manual de análise química do solo e controle de qualidade. Londrina: Instituto Agronômico do Paraná, Circular 76. 1992.

29. Salton JC, Mercante FM, Tomazi M, Zanatta JA, Concenc G, Silva WM, Retore M. Integrated crop-livestock system in tropical Brazil: Toward a sustainable production system. Agric EcosEnviron 2014 (190):70-9.

30.SAS System. SAS Institute Inc. SAS OnlineDoc® 9.1.2. Cary, NC: SAS Institute. 2004.

31. Toffolli LCB, Assman NTS, Assmann AL, Cassol LC, Toffolli RB, Nicola V, Ferrazza J. Application limestone forms and doses for Alfalfa in no-tillage system. Rev Ciênc Agron 2014 (45-Especial):906-13.

(C) 2020 by the authors. Submitted for possible open access publication under the terms and conditions of the Creative Commons Attribution (CC BY NC) license (https://creativecommons.org/licenses/by-nc/4.0/). 